\title{
Intra-class variability in the carbon, pigment and biomineral content of prymnesiophytes and diatoms
}

\author{
C. A. Llewellyn ${ }^{1, *}$, S. W. Gibb ${ }^{2}$ \\ 'Centre for Coastal and Marine Sciences, Plymouth Marine Laboratory, Prospect Place, West Hoe, Plymouth PL1 3DH, \\ United Kingdom \\ ${ }^{2}$ Environmental Research Institute, Castle Street, Thurso, Caithness KW14 7JD, United Kingdom
}

\begin{abstract}
Chlorophyll (chl) and carotenoid pigment data has significantly advanced our understanding of the distribution and class composition of phytoplankton biomass. However, the conversion of this data into quantitative and reliable estimates of biomass necessitates empirical carbon and pigment measurements on individual species. We have studied the carbon, pigment (chl and carotenoid) and biomineral (silicate and calcite) content of 20 prymnesiophytes and diatoms as key representatives of ecologically important phytoplankton in marine temperate waters. Batch cultures were sampled for each analysis in triplicate during early and late growth periods. To enable intra-class comparisons, pigment/chl a ratios are presented as are cellular constituent densities derived by normalising concentrations with cellular counts and volumes. For both prymnesiophytes and diatoms in early growth, chl a and carbon density were found to decrease from 8 to $<2 \mathrm{fg} \mu \mathrm{m}^{-3}$ and from 0.5 to $<0.1 \mathrm{pg}^{-3} \mathrm{~m}^{-3}$ respectively as cell volume increased from 20 to $>1000 \mu^{3}$. Pigment densities often decreased for the late growth period whereas carbon concentrations increased rapidly (up to 6 -fold), resulting in a decrease in chl a/carbon ratio from an average 0.02 to 0.01 . Regressions of POC and biovolume indicated that between 40 and $80 \%$ of the total POC for cells harvested during late growth was due to non-viable material. In addition, we found that chemotaxonomic marker pigments did not correlate with biominerals for either diatoms (fucoxanthin with silicate), or prymnesiophytes (19'hexanoyloxyfucoxanthin with calcite). Our empirical data, which are presented for a wider range of species than previously available, strengthen the basis upon which quantitative estimations of phytoplankton biomass in aquatic ecosystems are reliant.
\end{abstract}

KEY WORDS: Prymnesiophytes · Diatoms · Carbon $\cdot$ Chlorophylls $\cdot$ Carotenoids $\cdot$ Calcite $\cdot$ Silicate

'Only by studying individual biologies will we improve our understanding of the forces shaping ecosystem structure and driving biogeochemical fluxes'

Verity \& Smetacek (1996)

\section{INTRODUCTION}

Prymnesiophytes and diatoms are 2 phytoplankton classes that often dominate the base of the food chain in temperate marine waters and may have a profound influence on global biogeochemistry. Diatoms, charac-

-E-mail: call@ccms.ac.uk terised by silica frustules, are ubiquitous in temperate oceans and dominate nutrient-enriched waters such as those found in upwelling regions and at the onset of the spring bloom. Following the spring bloom, nitrate and silicate become depleted and prymnesiophytes succeed in dominating the upper water column biomass while diatomaceous material dominates the flux of material sinking out of the water column (Sieracki et al. 1993, Weeks et al, 1993, Llewellyn \& Mantoura 1996). Coccolithophorids, an important component of the prymnesiophyte biomass, play an important role in oceanic carbon cycling by transporting calcium carbonate from the upper oceanic layers to the abyssal sediments (Takahashi 1994). 
Table 1 Taxonomic designation, cell counts and volumes for early (1st harvest) and late (2nd harvest) cell harvests ( 1 and 2 respectively) as described in text. Standard deviations (\%) are given in parentheses

\begin{tabular}{|c|c|c|c|c|c|c|c|c|}
\hline \multirow[t]{2}{*}{$\begin{array}{l}\text { Class } \\
\text { Order }\end{array}$} & \multirow[t]{2}{*}{ Culture code } & \multirow[t]{2}{*}{ Species } & \multicolumn{2}{|c|}{$\begin{array}{l}\text { Cell count } \\
\left.\text { (cells } \mathrm{ml}^{-1}\right)\end{array}$} & \multicolumn{2}{|c|}{ Growth phase ${ }^{c}$} & \multicolumn{2}{|c|}{$\begin{array}{c}\text { Cellular volume } \\
\left.\qquad\left(\mu^{\mathrm{d}}\right)^{3}\right)\end{array}$} \\
\hline & & & 1 & 2 & 1 & 2 & 1 & 2 \\
\hline \multicolumn{9}{|l|}{ Prymnesiophyceae" } \\
\hline \multirow[t]{4}{*}{ Prymnesiales } & PLY $-143^{\prime}$ & Chrysochromulina brevifilum & $1.48 \mathrm{E}+05(11)$ & $5.74 \mathrm{E}+03(73)$ & $\mathrm{L}$ & $\mathrm{D}$ & 63 & 63 \\
\hline & PLY $-43^{a}$ & Chrysochromulina strobilus & $1.18 \mathrm{E}+05(14)$ & $5.38 \mathrm{E}+04(26)$ & $\mathrm{L}$ & $\mathrm{D}$ & 105 & 76 \\
\hline & PLY -559 & Chrysochromulina sp. & $1.41 \mathrm{E}+05(1.4)$ & $4.04 \mathrm{E}+05(20)$ & $\mathrm{L}$ & $\mathrm{S}$ & 44 & 40 \\
\hline & PLY-64 & Phaeocystis pouchetii & $2.28 E+05(15)$ & $2.82 \mathrm{E}+05(20)$ & $\mathrm{L}$ & $\mathrm{D}$ & 19 & 24 \\
\hline \multirow[t]{2}{*}{ Coccolithophorales } & PLY $-182^{9}$ & Coccolithus pelagicus & 1.12E+04 $(39)$ & $6.33 \mathrm{E}+03(100)$ & $\mathrm{L}$ & $\mathrm{S}$ & $1295^{\mathrm{h}}$ & $617^{\mathrm{h}}$ \\
\hline & $\mathrm{PLY}-61 / 7 / 3$ & Emiliania huxleyi & $3.78 \mathrm{E}+05(15)$ & $4.75 \mathrm{E}+05(9)$ & $\mathrm{L}$ & $\mathrm{S}$ & $39^{\mathrm{h}}$ & $36^{n}$ \\
\hline \multirow[t]{2}{*}{ Pavlovales } & PLY-244 & Diacronema vklianum & $4.18 \mathrm{E}+05(17)$ & $3.86 \mathrm{E}+06(8)$ & $\mathrm{L}$ & $\mathrm{S}$ & 32 & 25 \\
\hline & $\mathrm{PLY}-471$ & Pavlova pinguis & $3.69 \mathrm{E}+05(14)$ & $1.25 \mathrm{E}+06(14)$ & $\mathrm{L}$ & $\mathrm{S}$ & 41 & 60 \\
\hline \multirow[t]{2}{*}{ Isochryidales } & PLY-B & Dicrateria inornata & $5.14 E+05(14)$ & $5.90 \mathrm{E}+05(12)$ & $\mathrm{L}$ & $\mathrm{S}$ & 16 & 12 \\
\hline & PLY-133 & Imantonia rotunda & $4.08 \mathrm{E}+05(16)$ & $3.26 \mathrm{E}+06(13)$ & $\mathrm{L}$ & $\mathrm{S}$ & 23 & 17 \\
\hline \multicolumn{9}{|l|}{ Bacillariophyceae ${ }^{\mathrm{e}}$} \\
\hline \multirow[t]{7}{*}{ Centrales } & CCAP- $1000 / 1^{\mathrm{g}}$ & Actinocyclus subtilis & $2.69 \mathrm{E}+02(33)$ & $5.03 E+02(42)$ & A & $\mathrm{L}$ & $20056^{\prime}$ & $20056^{\mathrm{i}}$ \\
\hline & CCAP-1009/2 & Asterionellopsis kariana & $7.99 E+04(25)$ & $5.11 \mathrm{E}+05(8)$ & $\mathrm{L}$ & $\mathrm{S}$ & 185 & 137 \\
\hline & CCAP-1010/11 & Chaetoceros calcitrans & $2.36 \mathrm{E}+05(17)$ & $4.66 \mathrm{E}+05(9)$ & $\mathrm{L}$ & $\mathrm{D}$ & 29 & 17 \\
\hline & CCAP-1010/6 & Chaetoceros debilis & $2.26 \mathrm{E}+05(19)$ & $4.85 \mathrm{E}+05(31)$ & $L$ & $\mathrm{D}$ & 125 & 47 \\
\hline & CCAP-1077/5 & Skeletonema costatum & $2.59 \mathrm{E}+05(20)$ & $1.17 \mathrm{E}+06(17)$ & $\mathrm{L}$ & $\mathrm{D}$ & 43 & 48 \\
\hline & CCAP-1084/1 & Thalassiosira weissflogii & $4.52 \mathrm{E}+04(31)$ & $2.68 \mathrm{E}+05(20)$ & $\mathrm{L}$ & $\mathrm{S}$ & 779 & 745 \\
\hline & CCAP- $1029 / 18$ & Fragilaria striatula & $1.37 \mathrm{E}+04(100)$ & $1.11 \mathrm{E}+05(31)$ & A & $\mathrm{L}$ & 98 & 162 \\
\hline \multirow[t]{3}{*}{ Pennales } & CCAP $-1050 / 8$ & Navicula hansenii & $1.08 \mathrm{E}+04(39)$ & $1.03 \mathrm{E}+05(29)$ & L & S & 33 & 61 \\
\hline & SMBA-302 & Pennate diatom & $1.13 \mathrm{E}+04(31)$ & $5.55 \mathrm{E}+04(27)$ & A & L & 92 & 120 \\
\hline & CCAP-1085/1 & Thalassionema nitzschioides & $3.42 E+05\lfloor 17\rceil$ & $5.65 \mathrm{E}+05(7)$ & $\mathrm{L}$ & $\mathrm{S}$ & 120 & 120 \\
\hline \multicolumn{9}{|c|}{${ }^{a}$ Taxonomic scheme for Prymnesiophyceae according to Chrétiennot-Dinet et al. (1993) } \\
\hline \multicolumn{9}{|c|}{ Determined from microscopic analysis } \\
\hline \multicolumn{9}{|c|}{${ }^{\mathrm{c}} \mathrm{A}, \mathrm{L}, \mathrm{S}$ and $\mathrm{D}$ denote acceleration, logarithmic, stationary and death phase respectively } \\
\hline \multicolumn{9}{|c|}{$\begin{array}{l}\text { 'Determined from multisizer data using } 1 \% \text { Lugol's fixation. Shrinkage }(1.33 \times) \text { due to fixation taken into account (Montagnes et al. } 1994) \text {. Standard deviation < } 10 \% \text {; } \\
\text { see text }\end{array}$} \\
\hline \multicolumn{9}{|c|}{ "Commonly referred to as prymnesiophytes and diatoms } \\
\hline \multicolumn{9}{|c|}{ 'PLY: Plymouth Culture Collection, CCMS-PML, Plymouth PL1 3DH, United Kingdom } \\
\hline \multicolumn{9}{|c|}{$\begin{array}{l}\text { 'CCAP: Culture Collection of Algae and Protozoa, CCMS-DML, Oban PA34 4AD, United Kingdom. SMBA: Scottish Marine Biological Association, Oban DA34 4AD, } \\
\text { United Kingdom }\end{array}$} \\
\hline \multicolumn{9}{|c|}{${ }^{n}$ Volume for naked cell: Lugol's fixation dissolves coccoliths } \\
\hline${ }^{\mathrm{i} C}$ Calculated from spherica & al diameter of 80 & & & & & & & \\
\hline
\end{tabular}


Our understanding of these 2 important classes in terms of distribution of and contribution to phytoplankton biomass has increased significantly in recent years (Williams \& Claustre 1991, Barlow et al. 1993, Llewellyn \& Mantoura 1996). This is in part due to the introduction of high performance liquid chromatography (HPLC) techniques which have been applied with great success to the analysis of phytoplankton chlorophylls and carotenoids (Mantoura \& Llewellyn 1983, Wright et al. 1991, Barlow et al. 1997). Chlorophyll a (chl a), ubiquitous in phytoplankton, is used to provide biomass estimates, whereas carotenoids are often associated with specific classes and their 'fingerprints' enable qualitative distribution patterns to be investigated. However, the conversion of these measurements into quantitative and reliable estimates of phytoplankton carbon biomass and class composition necessitates empirical carbon and pigment measurements on individual species. To date, there are few such published quantitative measurements.

The aim of this paper is to present and compare empirical measurements of carbon, chlorophylls, carotenoids, calcite and silicate in 20 prymnesiophyte and diatom species chosen as key representatives of temperate marine phytoplankton. Analyses were carried out on triplicate samples from batch culture harvestings from early growth and late growth. Concentrations are normalised using cellular volumes to provide cell constituent densities to facilitate comparisons between species and between the 2 phases of growth. Our results expand and update available pigment/ chl a ratios for the accurate use of recent factorial approaches (Mackey et al. 1996) to determine the contribution of individual classes of microalgae to total chl $a$. The possibility that biomarker pigments could be used as proxy markers for biomineral fluxes was also investigated. We thus provide empirical data strengthening the basis upon which quantitative estimations of phytoplankton in aquatic ecosystems are reliant.

\section{MATERIALS AND METHODS}

Algal cultures. Inoculates from 10 prymnesiophytes and 10 diatoms (Table 1) were transferred aseptically (although the cultures were not kept axenic) into $2.5 \mathrm{l}$ Erlenmeyer flasks and grown in $2.0 \mathrm{l}$ of $\mathrm{f} / 2$ culture medium with sodium metasilicate $(0.003 \% \mathrm{w} / \mathrm{v})$. Cultures were illuminated at an irradiance of 98 to 146 $\mu \mathrm{mol} \mathrm{m} \mathrm{m}^{-2} \mathrm{~s}^{-1}$ with 'daylight' fluorescent tubes (Philips) on a 12:12 h light:dark cycle, maintained at $15^{\circ} \mathrm{C}$ and mixed by swirling the flasks daily. Biomass and growth were monitored daily by measuring chl a using a Turner fluorometer (Yentsch \& Menzel 1963) and cell counts using a Coulter multisizer. Samples were taken for each parameter described below by filtering triplicate aliquots of culture on 2 occasions: the first during early growth (1st harvest) where cells were predominantly in logarithmic growth phase (Table 1), and the second during late growth (2nd harvest) where cells were predominantly in the stationary growth phase (Table 1).

Particulate carbon and nitrogen. Aliquots of culture (10 to $40 \mathrm{ml}$ ) were vacuum filtered $(<50 \mathrm{~mm} \mathrm{Hg}$ ) onto ashed $\left(12 \mathrm{~h}\right.$ at $450^{\circ} \mathrm{C}$ ) GF/F filters (25 mm, Whatman) and stored at $-20^{\circ} \mathrm{C}$. Prior to analysis, samples for total particulate carbon (TPC) and nitrogen were dried (12 h at $\left.40^{\circ} \mathrm{C}\right)$, transferred onto ashed aluminium discs (30 mm), crimped to produce pellets ( $2 \mathrm{~mm}$ diameter) and kept desiccated. For particulate organic carbon (POC), samples were dried, transferred to ashed aluminium discs, and then acidified with $400 \mathrm{\mu l}$ sulphurous acid to remove inorganic carbon (Verado et al. 1990). Samples were again dried and crimped into pellets. Pellets were analysed using an elemental analyser (Carlo Erba NA 1500) calibrated with acetinalide. Blanks, which were prepared in the same way as samples using un-inoculated culture media, were subtracted from samples. The contribution of heterotrophic bacterial carbon biomass was determined by using flow cytometric analysis of culture samples fixed with $0.1 \%$ glutaraldehyde and stained with the fluorescent dye SYBR green (Zubkov et al. in press, Glen Tarran, CCMS-PML, pers, comm.).

Calcite. Aliquots of culture (20 to $40 \mathrm{ml}$ ) were filtered onto GF/F filters ( $25 \mathrm{~mm}$, Whatman) and stored at $-20^{\circ} \mathrm{C}$ until analysis. Calcium was extracted with $1 \mathrm{ml}$ concentrated $\mathrm{HCl}$ at $40^{\circ} \mathrm{C}$ for 5 min in acid-washed borosilicate vials and then made up to $10 \mathrm{ml}$ with distilled water and $1 \mathrm{ml} \mathrm{10 \%} \mathrm{lanthanum} \mathrm{chloride} \mathrm{solution.} \mathrm{Calcium} \mathrm{con-}$ centration was determined by flame atomic absorption spectrometry (Varian AA20) using an air-acetylene flame at $422.7 \mathrm{~nm}$ (Fernandez et al. 1993).

Silicate. Aliquots of culture $(10 \mathrm{ml})$ were filtered onto Cyclopore polycarbonate membranes $(25 \mathrm{~mm}$, Whatman) and analysed using the method of Parsons et al. (1984). In summary: membranes were placed in $60 \mathrm{ml}$ acid-washed polypropylene bottles with $25 \mathrm{ml}$ of $85^{\circ} \mathrm{C}$ $0.1 \mathrm{M}$ sodium hydroxide. Samples were shaken for $2 \mathrm{~h}$ at $85^{\circ} \mathrm{C}$ followed by the addition of $25 \mathrm{ml} 1 \%$ sulphuric acid and $1 \mathrm{ml} 0.16 \mathrm{M}$ ammonium heptamolybdate. After $10 \mathrm{~min}, 1 \mathrm{ml} 0.8 \mathrm{M}$ oxalic acid and $1 \mathrm{ml}$ ascorbic acid were added and mixed vigorously. Samples were left to colour stabilise for $10 \mathrm{~min}$ and then absorption was measured at $810 \mathrm{~nm}$ using a UV/vis absorbance spectrophotometer (Perkin Elmer Lamba 2). Sodium hexafluorosilicate was used in the calibration at 6 concentrations ( 0.5 to $5 \mathrm{mg} \mathrm{Si} \mathrm{l}^{-1}$ ), using the same protocol. All reagents were analytical grade (Aldrich) and prepared using Milli-Q water. 


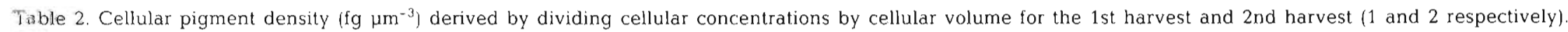
Chl $c_{3}=$ chlorophyll $c_{3 i}$ Chl $c_{1} \& c_{2}=$ chlorophyll $c_{1} \& c_{2}$ : But-fuco $=19^{\prime}$ butanoyloxyfucoxanthin; Hex-fuco $=19$ 'hexanoyloxyfucoxanthin; Diadino $=$ diadinoxanthin; Diato $=$ diatoxanthin; Chl $a=$ chlorophyll $a$; Phytol $c=$ phytolated chlorophyll $c_{2}$

\begin{tabular}{|c|c|c|c|c|c|c|c|c|c|c|c|c|c|c|c|c|c|c|c|c|}
\hline & \multicolumn{2}{|c|}{ Chl $c_{3}$} & \multicolumn{2}{|c|}{$\mathrm{Chl} c_{1} \& \cdot c_{2}$} & \multicolumn{2}{|c|}{ But-fuco } & \multicolumn{2}{|c|}{ Fuco } & \multicolumn{2}{|c|}{ Hex-fuco } & \multicolumn{2}{|c|}{ Diadino } & \multicolumn{2}{|c|}{ Diato } & \multicolumn{2}{|c|}{ Chl $a^{\mathrm{a}}$} & \multicolumn{2}{|c|}{ Phytol c } & \multicolumn{2}{|c|}{ Carotene } \\
\hline & 1 & 2 & 1 & 2 & 1 & 2 & 1 & 2 & 1 & 2 & 1 & 2 & 1 & 2 & 1 & 2 & 1 & 2 & 1 & 2 \\
\hline \multicolumn{21}{|l|}{ Prymnesiophylus } \\
\hline Chrysochromulina brevifilum & 0.40 & 0.11 & 0.91 & 0.25 & 0.05 & 0.08 & 0.11 & 0.07 & 3.86 & 1.32 & 1.37 & 0.44 & 0.08 & 1.20 & 5.46 & 5.38 & 0.28 & - & 0.12 & - \\
\hline Chrysochromulina strobilus & 0.28 & 0.56 & 0.24 & 0.45 & 0.03 & 0.05 & 0.12 & 0.50 & 1.40 & 2.67 & 0.30 & 1.01 & 0.01 & 0.04 & 2.17 & 5.44 & 0.07 & 0.12 & 0.04 & 0.08 \\
\hline Chrysochromulina sp. & 0.66 & 0.50 & 0.83 & 0.65 & 0.06 & 0.01 & 0.07 & 0.03 & 4.79 & 4.04 & 0.82 & 1.21 & 0.12 & 0.22 & 5.59 & 4.10 & 0.08 & 0.15 & 0.09 & 0.08 \\
\hline Phaeocystus pouchetii & 0.79 & 0.45 & 1.33 & 0.61 & 0.14 & 0.12 & 3.62 & 2.02 & 0.54 & 0.61 & 1.37 & 1.63 & 0.41 & 0.62 & 7.38 & 3.93 & 0.30 & 0.17 & 0.13 & 0.05 \\
\hline Coccolithus pelagicus & 0.08 & - & 0.25 & 0.23 & 0.01 & -- & 0.72 & 0.56 & 0.08 & 0.02 & 0.22 & 0.13 & 0.05 & 0.28 & 1.41 & 1.39 & 0.04 & - & 0.02 & 0.02 \\
\hline Emiliania huxleyi & 0.33 & 0.24 & 0.89 & 0.62 & 0.04 & 0.01 & 0.35 & 0.16 & 2.24 & 2.00 & 0.90 & 0.98 & 0.19 & 0.33 & 3.69 & 3.62 & 0.13 & 0.09 & 0.05 & 0.07 \\
\hline Diacronema vklianum & - & - & 0.12 & 0.12 & - & - & 0.58 & 0.47 & - & - & 1.20 & 1.48 & 0.27 & 0.45 & 4.13 & 2.83 & - & - & 1.35 & 2.44 \\
\hline Pavlova pinguis & 0.01 & - & 0.30 & 0.17 & - & - & 0.97 & 0.58 & - & - & 0.79 & 1.14 & 0.20 & 0.58 & 3.77 & 2.98 & 0.01 & 0.02 & 0.36 & 0.66 \\
\hline Dicrateria inornata & 0.88 & 0.70 & 1.22 & 0.79 & 0.72 & 0.31 & 0.36 & 0.17 & 4.94 & 3.92 & 0.96 & 0.02 & 0.21 & 0.75 & 6.69 & 5.38 & 0.19 & 0.13 & 0.14 & 0.10 \\
\hline Imantonla rotunda & 1.56 & 1.17 & 1.96 & 0.83 & 1.07 & 0.44 & 1.44 & 0.24 & 6.18 & 4.53 & 2.28 & 1.77 & 0.84 & 1.04 & 6.35 & 5.87 & 0.20 & 0.15 & 0.20 & 0.14 \\
\hline Average & 0.55 & 0.53 & 0.81 & 0.47 & 0.27 & 0.15 & 0.83 & 0.48 & 3.00 & 2.39 & 1.02 & 0.98 & 0.24 & 0.55 & 4.56 & 4.09 & 0.14 & 0.12 & 0.25 & 0.40 \\
\hline $\mathrm{SD}$ & 0.48 & 0.34 & 0.59 & 0.26 & 0.40 & 0.17 & 1.07 & 0.58 & 2.25 & 1.68 & 0.59 & 0.61 & 0.24 & 0.37 & 1.96 & 1.44 & 0.10 & 0.05 & 0.40 & 0.79 \\
\hline \multicolumn{21}{|l|}{ Diatoms } \\
\hline Actinocyclus subtills & - & - & 0.02 & 0.04 & - & - & 0.08 & 0.12 & - & - & 0.02 & 0.03 & 0.01 & 0.02 & 0.16 & 0.26 & - & - & 0.01 & 0.01 \\
\hline Asterionellopsis kariana & 0.02 & 0.02 & 0.38 & 0.27 & - & - & 0.76 & 0.68 & - & - & 0.10 & 0.28 & 0.04 & 0.11 & 2.23 & 1.32 & - & - & 0.04 & 0.02 \\
\hline Chaetoceros calcitrans & - & - & 0.64 & 0.06 & - & - & 1.78 & 0.25 & - & - & 0.94 & 0.19 & 0.37 & 0.43 & 6.44 & 0.92 & - & - & 0.17 & 0.03 \\
\hline Chaetoceros debilus & - & - & 1.14 & 0.11 & - & - & 1.43 & 0.45 & - & - & 0.21 & 0.17 & 0.02 & 0.26 & 3.62 & 1.34 & - & - & 0.06 & 0.05 \\
\hline Skeletonema costatum & - & - & 1.68 & 0.29 & - & - & 1.18 & 0.02 & - & - & 0.17 & - & 0.05 & - & 8.23 & 0.33 & - & - & 0.08 & - \\
\hline Thulassiosira weissflogii & - & - & 0.25 & 0.23 & - & - & 0.88 & 0.71 & - & - & 0.71 & 0.68 & 0.26 & 0.42 & 3.60 & 2.65 & - & - & 0.09 & 0.08 \\
\hline Fragulana striatula & - & - & 0.20 & 0.93 & - & - & 0.33 & 1.84 & - & - & 0.05 & 0.16 & - & 0.02 & 1.53 & 10.13 & - & - & - & 0.09 \\
\hline Navicula hansenii & - & - & 0.43 & 0.20 & - & - & 1.57 & 0.89 & - & - & 0.44 & 0.43 & - & 0.17 & 3.74 & 2.83 & - & - & 0.05 & 0.06 \\
\hline Pennate diatom & - & - & 0.46 & 0.47 & - & - & 1.89 & 1.50 & - & - & 0.54 & 0.82 & 0.02 & 0.33 & 4.71 & 3.50 & - & - & 0.09 & 0.05 \\
\hline Thaldssionema mitzschioides & - & - & 0.56 & 1.20 & - & - & 0.42 & 1.85 & - & - & 0.11 & 0.76 & 0.12 & 0.52 & 2.08 & 6.40 & - & - & 0.03 & 0.08 \\
\hline Average & - & - & 0.64 & 0.42 & - & - & 1.14 & 0.91 & - & - & 0.36 & 0.44 & 0.13 & 0.28 & 3.63 & 2.97 & - & - & 0.08 & 0.06 \\
\hline SD & - & - & 0.48 & 0.39 & - & - & 0.57 & 0.67 & - & - & 0.31 & 0.28 & 0.14 & 0.17 & 2.38 & 3.11 & - & - & 0.04 & 0.02 \\
\hline
\end{tabular}


Chlorophylls and carotenoids. Aliquots of culture (10 to $40 \mathrm{ml}$ ) were filtered on to GF/F filters and stored in liquid nitrogen. Pigments were extracted from the filter by ultrasonication and centrifugation using $2 \mathrm{ml}$ methanol and analysed using the method described by Barlow et al. (1997) with a reverse-phase gradient HPLC system (Thermo Separation Products). Absorbance was monitored continuously between 300 and $700 \mathrm{~nm}$ and the pigments were quantified using canthaxanthin as an internal standard (Gibb et al. in press).

Cell counts and volumes. Aliquots of culture $(100 \mathrm{ml})$ were preserved in $1 \%$ acid Lugol's iodine and stored in the dark at room temperature. Cells were counted using an inverted microscope (Olympus IMT-2) and counts averaged for 20 fields of view (average of 50 cells per field of view). In addition, cell counts and cell volumes were determined using a multisizer counter (Coulter II).

Microscopy data provided a more accurate estimate of cell counts than multisizer data and therefore we used these to calculate cell concentrations (Table 1). It is more difficult to ascertain the errors associated with cellular volume estimates. The standard deviation of cellular volumes calculated from multisizer data was less than $10 \%$ (Table 1). However, the multisizer assumes that cells have a spherical shape, and although this is true for most prymnesiophytes it is not true for some of the diatoms. Therefore, for non-spherical, chain-forming and clumping cells we obtained estimates of volume from microscopic analysis according to the basic geometry of the cell, e.g. sphere, cuboid and oblate ellipsoid. There is little published on cellular volumes; however, our calculated volumes were in the same range as those obtained by Montagnes et al. (1994), D. Harbour (unpubl. data) and C. Saunders (unpubl. data).

\section{RESULTS}

\section{Pigments}

\section{Prymnesiophytes}

All prymnesiophytes studied, except those in the order Pavlovales (i.e. Diacronema vklianum and Pavlova pinguis), contained chlorophyll a (chl a), chlorophyll $c_{3}$ (chl $c_{3}$ ), chlorophyll $c_{1}$ and $c_{2}\left(\mathrm{chl} c_{1} \& c_{2}\right)$, 19'butanoyloxyfucoxanthin (but-fuco), 19'hexanoyloxyfucoxanthin (hex-fuco), fucoxanthin (fuco), diadinoxanthin (diadino), diatoxanthin (diato) and $\beta, \beta$ carotene (Table 2). The Pavlovales had a pigment distribution more characteristic of diatoms, i.e. they were deficient in chl $c_{3}$, but-fuco and hex-fuco, and they contained $\beta, \varepsilon$-carotene in addition to $\beta, \beta$ carotene

The cellular concentration of pigments per unit volume (cellular density; Table 2) was highest for chl a. This was followed by, in decreasing order, hex-fuco (average $65 \%[\mathrm{~g} / \mathrm{g}]$ of $\mathrm{chl}$ a), diadino (average $22 \%$ of chl a), fuco (average $18 \%$ of chl a), chl $c_{1}$ and $c_{2}$ (average $17 \%$ of $\mathrm{chl} \mathrm{a}$ ), chl $c_{3}$ (average $12 \%$ of $\mathrm{chl}$ a) and finally by but-fuco, diato and carotene, which had similar densities (average $5 \%$ of $\mathrm{chl}$ a). Exceptions were for: Diacronema vklianum and Pavlova pinguis, which were absent in hex-fuco, and had a carotene density higher than that of fuco; Phaeocystis pouchetii and Coccolithus pelagicus, in which fuco dominated over hex-fuco; Dicrateria inornata and Imantonia rotunda (both in the order Isochryidales), in which but-fuco density was similar to that of fuco.

Pigment densities in cells from the 2 nd harvest were generally less (by up to $80 \%$ ) than for cells at 1st harvest, with chl a showing the least change (Table 2). Exceptions were diadino and carotene, which increased in density by up to 2.4 -fold, and diato, which increased by up to 16 -fold.

\section{Diatoms}

All diatoms contained $\mathrm{chl} c_{1} \& c_{2}$, fuco, diadino, diato, chl $a$ and $\beta, \beta$-carotene (Table 2). In addition Asterionellopsis subtilus contained low amounts of chl $c_{3}$

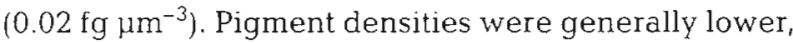
although more variable, in the diatoms than in the prymnesiophytes. Chl a had the highest density, followed by fuco (average $30 \%$ of $\mathrm{chl}$ a), chl $c_{1} \& c_{2}$ (average $17 \%$ of chl a), diadino (average $10 \%$ of chl a), diato (average $3 \%$ of chl a) and carotene (average $2 \%$ of chl a) (Table 2). Chl a allomer and chlorophyllide $a$, whose formation is most likely triggered as an extraction artefact in ageing or stressed cultures, were present in some diatoms (Table 2). Interestingly fuco and chl $c_{1} \& c_{2}$, frequently used as key markers of diatoms, were often present at a lower density in the diatoms than in the prymnesiophytes.

Pigment densities in diatom cells from the 2nd harvest were generally lower than those from the 1st harvest (except for diadino and diato, and chl a allomer and chlorophyllide a) and showed larger decreases (up to $98 \%$ ) compared to the prymnesiophytes. Exceptions were for Fragilaria striatula and Actinocyclus subtilus, whose densities increased, likely as a result of the 2 nd harvest being in log phase (Table 1), and for Thalassionema nitzschioides. Diadino and diato densities were lower overall in diatoms than in prymnesiophytes but showed a similar pattern of change at the 2 nd harvest to that found for prymnesiophytes. 
Table 3. Total particulate carbon (TPC), C/N, chlorophyll a (Chl)/C and mineral content for 1st harvest and 2 nd harvest (1 and 2 respectively). Value is the mean for triplicate analysis with standard deviation in parentheses

\begin{tabular}{|c|c|c|c|c|c|c|c|c|c|c|c|c|c|c|c|c|}
\hline & \multicolumn{2}{|c|}{ TPC } & \multicolumn{2}{|l|}{ TPC } & \multicolumn{2}{|c|}{$\mathrm{C} / \mathrm{N}$} & \multirow{2}{*}{\multicolumn{2}{|c|}{$\mathrm{Chl} / \mathrm{C}$}} & \multirow{2}{*}{\multicolumn{4}{|c|}{$\begin{array}{c}\mathrm{SiO}_{2} \\
\left(\mu \mathrm{l}^{-1}\right) \quad\left(\mu \mathrm{g}^{-1}\right)\left(\mathrm{pg} \mathrm{cell} l^{-1}\right)\left(\mathrm{pg} \mu \mathrm{m}^{-3}\right)\end{array}$}} & \multicolumn{4}{|c|}{$\mathrm{C}$ in $\mathrm{CaCO}_{3}$} \\
\hline & \multirow{2}{*}{$\begin{array}{c}\left(\left.\mu g\right|^{-1}\right) \\
1\end{array}$} & \multirow{2}{*}{$\begin{array}{c}\left(\mu g \mathrm{I}^{-1}\right) \\
2\end{array}$} & \multirow{2}{*}{$\begin{array}{c}\left(\mathrm{pg} \text { cell }{ }^{-1}\right) \\
1\end{array}$} & \multirow{2}{*}{$\begin{array}{c}\left(\mathrm{pg} \mu \mathrm{m}^{-3}\right) \\
1\end{array}$} & \multirow[b]{2}{*}{1} & \multirow[b]{2}{*}{2} & & & & & & & \multicolumn{4}{|c|}{$\left(\mu \mathrm{gl}^{-1}\right)\left(\mu \mathrm{gl}^{-1}\right)\left(\mathrm{pg}\right.$ cell $\left.^{-1}\right)\left(\mathrm{pg} \mu \mathrm{m}^{-3}\right)$} \\
\hline & & & & & & & 1 & 2 & $\begin{array}{c}\left(\mu g l^{-1}\right) \\
1\end{array}$ & 2 & 1 & 1 & 1 & 2 & 1 & 1 \\
\hline \multicolumn{17}{|l|}{ Prymnesiophytes } \\
\hline Chyrsochromulina brevifilum & $2928(7.6)$ & $2431(9.2)$ & $19.8(19)$ & 0.32 & 5.2 & 3.8 & 0.0173 & 0.0003 & 333 & 725 & 2.3 & 0.036 & - & - & - & - \\
\hline Chyrsochromulina strobilus & $2225(6.3)$ & $2655(14)$ & $18.9(20)$ & 0.18 & 5.5 & 5.2 & 0.0121 & 0.0084 & 403 & 497 & 3.4 & 0.032 & - & - & - & - \\
\hline Chrysochromulina sp. & $1334(22)$ & $5709(8)$ & $9.5(36)$ & 0.22 & 5 & 5.6 & 0.0259 & 0.0116 & 627 & 693 & 4.5 & 0.102 & 214 & & 1.5 & 0.03 \\
\hline Phaeocystis pouchetii & $1607(23)$ & $3427\{5\}$ & $7 \quad(38)$ & 0.38 & 4 & 2.3 & 0.0191 & 0.0077 & 497 & 743 & 2.2 & 0.117 & - & - & - & - \\
\hline Coccolithus pelagıcus & 2578 & $5735(26)$ & $230.2(>39)$ & 0.18 & & 7.9 & $0.034^{\mathrm{d}}$ & $0.0019^{a}$ & 301 & 844 & 26.9 & 0.021 & 1975 & 2827 & 176.3 & 0.14 \\
\hline Emiliania huxleyi & $6493(8)$ & $16280(2)$ & $17.2(23)$ & 0.44 & 12.3 & 8.8 & $0.0135^{\circ}$ & $0.0080^{\mathrm{a}}$ & 413 & 1073 & 1.1 & 0.029 & 2530 & 8556 & 6.7 & 0.17 \\
\hline Diacronema vkhanum & $2657(6)$ & 27263 (1) & $6.4(23)$ & 0.20 & 3.9 & 5.6 & 0.0189 & 0.0189 & 249 & 904 & 0.6 & 0.019 & - & - & - & - \\
\hline Pavlova pinguis & $3009(9)$ & $18017(10)$ & $8.2(23)$ & 0.20 & 8 & 7.6 & 0.0173 & 0.0117 & 631 & 10643 & 1.7 & 0.041 & - & 882 & - & - \\
\hline Dicrateria inornata & $2262(12)$ & $5290(5)$ & $4.4(26)$ & 0.28 & 4.6 & 3.6 & 0.0243 & 0.0072 & 314 & 578 & 0.6 & 0.038 & - & - & - & - \\
\hline Imantonia rotunda & 3644 & 23070 & $8.9(>16)$ & 0.39 & 5.7 & 5.6 & 0.0161 & 0.0143 & 470 & 603 & 1.2 & 0.051 & - & 474 & - & - \\
\hline Average & 2874 & 10988 & & 0.28 & 6.0 & 5.6 & 0.0189 & 0.0100 & 424 & 1730 & 4.4 & 0.049 & & & & \\
\hline SD & 1438 & 9286 & & 0.10 & 2.6 & 2.0 & 0.0044 & 0.0055 & 133 & 3136 & 8.0 & 0.034 & & & & \\
\hline \multicolumn{17}{|l|}{ Diatoms } \\
\hline Actinocyclus subtilis & $1166(27)$ & $2474(12)$ & $4334.6(50)$ & 0.02 & 7.3 & 5.6 & 0.0128 & 0.0186 & 2001 & 5078 & 7438.7 & 0.021 & - & - & - & - \\
\hline Asterionellopsis kariana & 4293 & 7745 (13) & $53.7(>25)$ & 0.29 & 6.7 & 6.8 & 0.0077 & 0.0114 & 1405 & 6199 & 17.6 & 0.095 & - & - & - & - \\
\hline Chaetoceros calcitrans & 3061 (1) & $7138(2)$ & $13 \quad(18)$ & 0.44 & 5.4 & 4.9 & 0.0264 & 0.0010 & 2004 & 3246 & 8.5 & 0.290 & - & - & - & - \\
\hline Chaetoceros debilis & $2990(15)$ & $7794(1)$ & $13.2(34)$ & 0.11 & 4.9 & 4.2 & 0.0320 & 0.0017 & 2170 & 13952 & 9.6 & 0.077 & - & - & - & - \\
\hline Skeletonema costatum & 2340 & $15648(8)$ & $9 \quad(21)$ & 0.21 & 5 & 6 & 0.0342 & 0.0009 & 3406 & 12231 & 13.2 & 0.309 & - & - & - & - \\
\hline Thalassiosira weissflogii & 3905 (1) & $20067(18)$ & $86.4(32)$ & 0.11 & 6.9 & 5.4 & 0.0296 & 0.0230 & 2625 & 15068 & 58.1 & 0.074 & - & - & - & - \\
\hline Fragilaria striatula & 123 & 9061 (3) & $9 \quad(100)$ & 0.09 & & 6.7 & 0.0167 & 0.0122 & 423 & 6638 & 30.9 & 0.314 & - & - & - & - \\
\hline Navicula hansenii & $204 \quad(55)$ & $5049(39)$ & $18.9(94)$ & 0.57 & 5.2 & 4.2 & 0.0070 & 0.0030 & 451 & 1953 & 41.8 & 1.256 & - & - & - & - \\
\hline Pennate diatom & 559 & 2879 (19) & $49.5(>31)$ & 0.54 & 8.6 & 8.9 & 0.0090 & 0.0079 & 1745 & 2035 & 154.4 & 1.683 & - & - & - & - \\
\hline Thalassionema nitzschioides & $3332(1)$ & $14128(2)$ & $9.7(18)$ & 0.08 & 4.7 & 5 & 0.0231 & 0.0274 & 8677 & 17401 & 25.4 & 0.212 & - & - & - & - \\
\hline Average & 2197 & 9198 & & 0.25 & 6.1 & 5.8 & 0.0198 & 0.0107 & 2491 & 8380 & 780 & 0.433 & & & & \\
\hline $\mathrm{SD}$ & 1564 & 5723 & & 0.20 & 1.4 & 1.4 & 0.0105 & 0.0096 & 2354 & 5760 & 2340 & 0.566 & & & & \\
\hline
\end{tabular}




\section{Biominerals}

Calcite was observed in 5 of the prymnesiophytes and in none of the diatoms (Table 3 ). Only 2 prymnesiophytes, however, both in the order Coccolithophorales (i.e. Coccolithus pelagicus and Emiliania huxleyi), contained high calcite concentrations, with calcite-carbon accounting for between 39 and $76 \%$ of total particulate carbon (TPC) for both harvests. The calcite density was similar for both $C$. pelagicus and $E$.

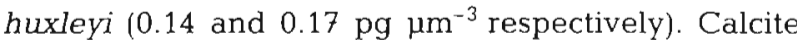
concentrations in the remaining 3 calcite-containing prymnesiophyte species (Chrysochromulina sp., Pavlova pinguis and Imantonia rotunda) were 10 -fold less, with calcite-carbon contributing to $<20 \%$ of TPC.

Silicate (Table 3) was present in both prymnesiophytes and diatoms. However, densities were on average 9 times lower in the prymnesiophytes $(0.05 \mathrm{pg}$ $\left.\mu \mathrm{m}^{-3}\right)$ than in the diatoms $\left(0.43 \mathrm{pg} \mu \mathrm{m}^{-3}\right)$. Prymnesiophyte silicate density was lowest for the 2 Coccolithophorales species and highest for Phaeocystis pouchetti, whose density was over twice the average value $\left(0.12 \mathrm{pg} \mathrm{\mu m}^{-3}\right)$. Prymnesiophyte silicate concentrations for the 2nd harvest increased 4-fold. Diatom silicate density was particularly high for Navicula hansenii and the pennate diatom (1.3 and $1.7 \mathrm{pg} \mathrm{um}^{-3}$ respectively) and low for the large-sized Actinocyclus subtilus $\left(0.02 \mathrm{pg} \mathrm{um}^{-3}\right)$. For the 2 nd harvest, diatom silicate concentrations increased on average by 3 -fold (i.e. similar to the increase for prymnesiophytes), with the largest increase in Fragilaria striatula, which had the lowest concentration for 1st harvest.

\section{Particulate carbon}

TPC concentrations are presented in Table 3. Bacteria contributed to $<10 \%$ of TPC and blanks were less than $1 \%$ of TPC. Inorganic and thus organic carbon concentrations (POC) derived from elemental analysis are not tabulated because inorganic carbon results were erroneously high, suggesting that some organic material had been volatilised together with carbonate after the addition of sulphurous acid. Similar errors have been found in other studies using the same analytical method (King et al. 1998). Subsequently, where we refer to POC, it is derived by subtracting calcite-carbon from TPC.

\section{Prymnesiophytes}

Although TPC ranged from 1334 to $6493 \mu \mathrm{g} \mathrm{l}^{-1}$ (average $2874 \pm 1438 \mu \mathrm{g} \mathrm{l}^{-1}$ ) for the 1st harvest, carbon per unit cell volume, i.e. carbon densities, was more uniform (average $0.28 \pm 0.10 \mathrm{pg} \mu \mathrm{m}^{-3}$ ). Carbon density was highest for Emiliania huxleyi (0.44 $\mathrm{pg} \mathrm{um}^{-3}$ ), possibly due to the $39 \%$ contribution from calcite-carbon. Carbon density was also high for Phaeocystis pouchetti $\left(0.38 \mathrm{pg} \mu \mathrm{m}^{-3}\right)$, which contained high silicate density, and for Imantonia rotunda.

For the 2nd harvest, TPC concentrations increased in all cultures by an average of 4 -fold (except for Chrysochromulina brevifilum, which declined). These higher TPC concentrations were, in part, caused by higher cell numbers and by the large numbers of lysed cells observed in the microscopic analysis (see Fig. 1).

The $\mathrm{C} / \mathrm{N}$ ratio for the 1 st harvest, excluding calcite carbon, was between 4 (Phaeocystis pouchetti, Diacronema vklianum) and 8 (Emiliania huxleyi, Pavlova pinguis), averaging close to the Redfield ratio (Takahashi et al. 1985). At the 2nd harvest there were slight changes in the $\mathrm{C} / \mathrm{N}$ ratio, with an overall slight decrease, with E. huxleyi showing the largest decrease to a $\mathrm{C} / \mathrm{N}$ of 4 .

\section{Diatoms}

The range of TPC at the 1st harvest was larger for diatoms than for prymnesiophytes (123 to $3905 \mu \mathrm{g} \mathrm{l}^{-1}$ ) as was the range in carbon density $(0.02$ to $0.57 \mathrm{pg}$ $\left.\mu \mathrm{m}^{-3}\right)$. However, average densities were similar for diatoms and prymnesiophytes $\left(0.25\right.$ and $\left.0.28 \mathrm{pg} \mathrm{\mu m}^{-3}\right)$. At the 2nd harvest diatom-TPC increased by the same amount as for the prymnesiophytes, i.e. 4 -fold. $\mathrm{C} / \mathrm{N}$ ratios for diatoms averaged at 6.0 for the 1 st harvest and decreased by a similar amount to the prymnesiophytes at the 2 nd harvest, i.e. to an average of 5.8 .

\section{DISCUSSION}

\section{Pigment ratios}

Quantification of the abundance of various phytoplanktonic classes from marker pigment concentrations requires accurate pigment/chl a ratios (pigment ratios). However, there is little published information on pigment ratios: the most thorough study for quantifying pigments at the class level is by Jeffrey \& Wright (1994), who tabulated the cellular concentration for 16 prymnesiophyte species. The few earlier attempts at quantifying prymnesiophyte biomass used less advanced chromatographic techniques (Berger et al. 1977), and the only survey of pigment diversity for diatoms (Stauber \& Jeffrey 1983) used the cruder analytical technique of thin layer chromatography, where quantification was difficult although data were presented for $\mathrm{chl} a$ and $c$.

The limited set of ratios from the above citations, together with ratios for 1 or 2 other species, is summarised by Mackey et al. (1996) for use in a matrix fac- 


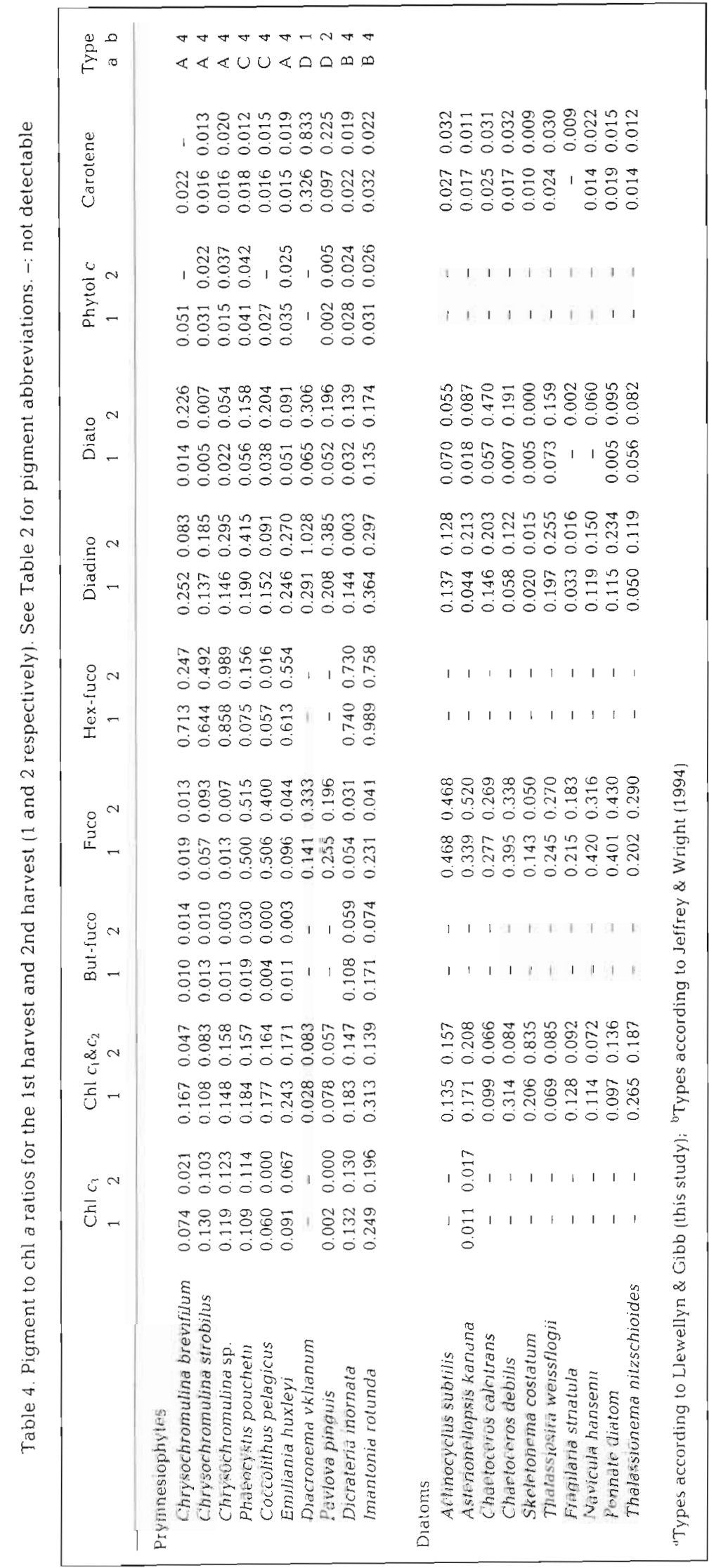

torization 'CHEMTAX' program for quantitative estimates of class abundances. Mackey et al. (1996) have developed a PCbased computer program ('CHEMTAX') based on factor analysis which requires an initial input of a pigment ratio matrix which is then used iteratively to obtain class abundances. The ratios used in this program are for log-phase cells only and therefore do not take into account changes in ratios that may occur in proceeding growth phases. Our results provide a more comprehensive assessment of the ratios for the prymnesiophytes and diatoms and highlight the extensive intra-class and intra-species variability (Table 4). Our pigment ratios generally fall within the ranges reported by Mackey et al. (1996) although we often found minimum values lower than those quoted for chl $c_{3}$, chl $c_{2}$, butfuco and fuco and higher values for carotene, as shown in Table 5

We found consistently higher diato and diadino ratios at 2 nd harvest compared to the 1st harvest. The large changes in diadino and diato/chl a ratios between the 2 harvests are similar to changes observed in aging benthic diatoms by Klein (1988), who suggested that such changes may be related to nutrient limitation. We conclude that such large changes in diadino and diato/chl a ratios preclude their use in estimating biomass contributions.

Using our pigment ratios (Table 4) we have divided the prymnesiophytes studied into 4 pigment types and have tabulated the minimum and maximum ratios for these in Table 5. These types can be summarised as: Type A with low fuco ratios (0.013 to 0.096); Type B with high but-fuco ratios $(0.059$ to 0.171$)$; Type $C$ with high fuco ratios (0.4 to 0.515$)$, i.e. comparable to that in diatoms; and Type $\mathrm{D}$ with no butfuco and hex-fuco, with high carotene ratios $(0.097$ to 0.833$)$ and with low phytol $c$ ratios $(<0.005)$. Our 4 types are identical to the morphological taxonomic order scheme proposed by Chrétiennot-Dinet et al. (1993) (Table 1) excepting Emiliania huxleyi and Phaeocystis pouchetii. However, this classification differs slightly to the chemotaxonomic types suggested by Jeffrey \& Wright (1994) (Table 5) and subsequently used by Mackey et al. (1996) for estimating phytoplankton distribution. 
Pigment ratios for the diatoms show no clear divisions within the 10 species studied (Table 5). Our ratios concur with those used by Mackey et al. (1996), with the exception that we found $\mathrm{chl} \mathrm{C}_{3}$ in the diatom Asterionellopsis subtilus, and that the chl $c_{1} \& c_{2}$ ratio was high and the fuco ratio low for Skeletonema costatum.

\section{Physiological and biochemical changes}

Microalgae grown in batch culture rapidly become self shading and nutrient depleted. Such conditions mimic to some extent conditions during and proceeding a spring bloom. Our results show that microalgae change physiologically and biochemically according to growth conditions. Our cultures reached maximum chl a concentrations in about $10 \mathrm{~d}$, after which there was a rapid decline, indicating that either senescence and/or bacterial or viral attack had occurred, resulting in destruction of cellular structure and the photosynthetic pigment system.

Pigment concentrations were found to decrease faster than cell numbers as growth progressed, resulting in a decrease in cellular pigment content, and indicating that the photosynthetic system is destroyed ahead of other cellular components. Few pigment transformation products of the chlorophylls (e.g. pheophorbides, pheophytins; Owens \& Falkowski 1982) or the carotenoids (e.g. cis-carotenoids, ester-hydrolysed products; Repeta \& Gagosian 1982) were detected at the 2 nd harvest, indicating that the tetrapyrrolic structure of chlorophyll and the isoprenoid structure of carotenoid are rapidly cleaved into products that are undetectable during HPLC pigment analysis. These observations suggest that a similar process of mass chlorophyll and cell destruction could occur at the end of a spring bloom without zooplankton herbivory being involved.

Overall diatom pigments degraded more rapidly than those of prymnesiophytes from the 1 st harvest to the 2 nd harvest. This may be because silicate depletion occurred in the diatom cultures or that prymnesiophytes are better able to cope with nutrient limitation. The $\mathrm{C} / \mathrm{N}$ ratio of prymnesiophyte and diatom cells was close to the Redfield ratio for the 1 st harvest, and did not increase at the 2 nd harvest, suggesting that the cultures were not nitrogen limited.

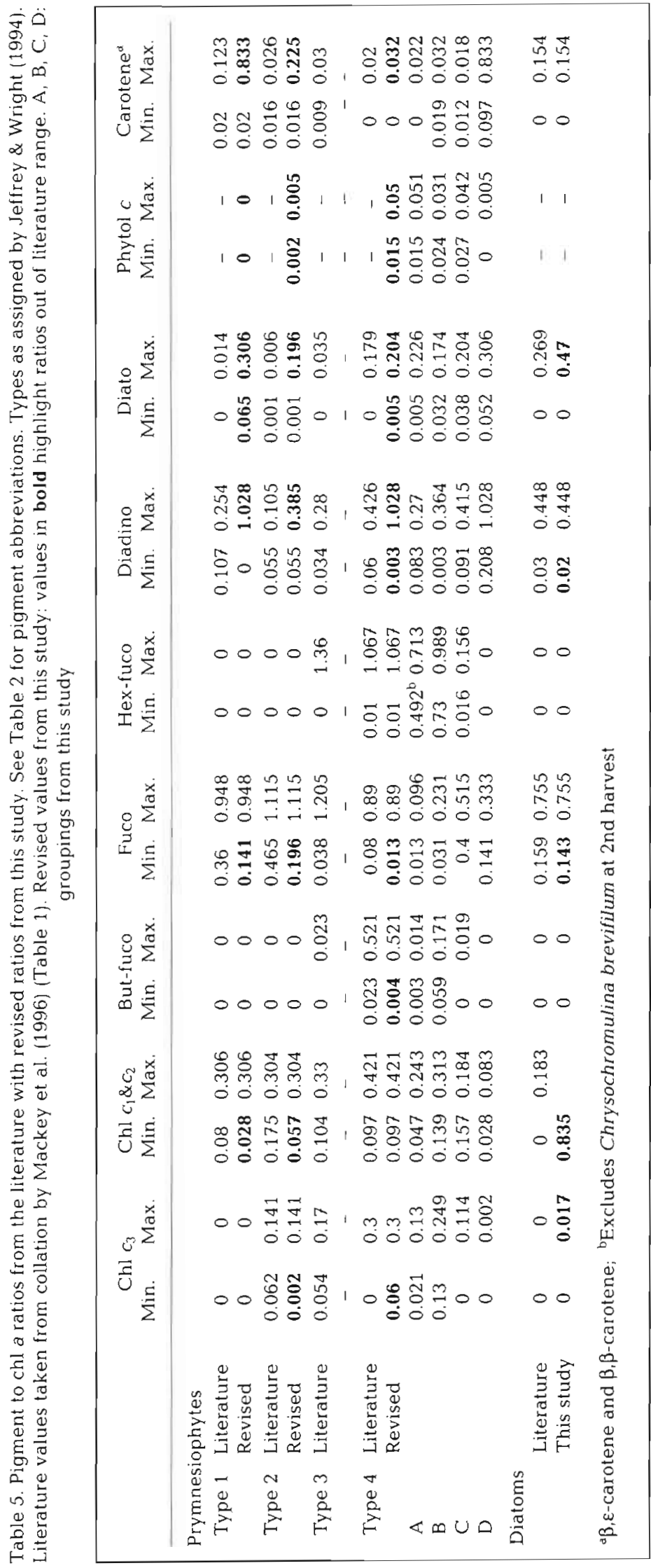



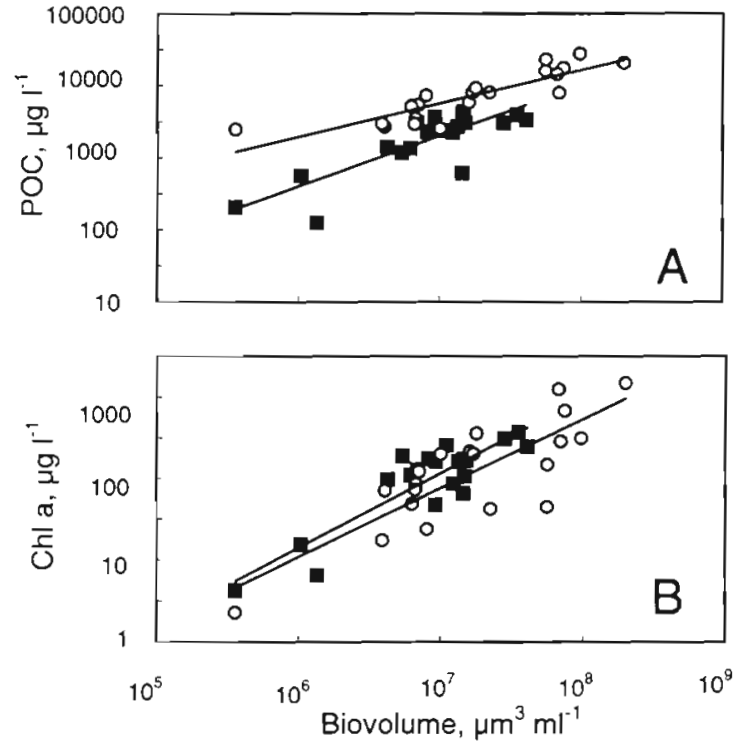

Fig. 1. (A) Particulate organic carbon (POC) and (B) chlorophyll a (chl a) versus biovolume $(V)$, for early (1st harvest, $\mathbf{n}$ ) and late growth (2nd harvest, 0 ).

1st harvest: $\log _{10} \mathrm{POC}=0.699 \log _{10} V-1.596$,

$\mathrm{r}^{2}=0.67, \mathrm{p}<0.0001$

2nd harvest: $\log _{10} \mathrm{POC}=0.462 \log _{10} V-0.518$,

$\mathrm{r}^{2}=0.75, \mathrm{p}<0.0001$;

1st harvest: $\log _{10} \mathrm{chl} a=0.91 \log _{10} V-4.813$,

$r^{2}=0.78, p<0.0001$;

2nd harvest: $\log _{10} \mathrm{chl} \alpha=0.844 \log _{10} V-4.531$, $\mathrm{r}^{2}=0.67, \mathrm{p}<0.0001$

Chl a:carbon ratios for both prymnesiophytes and diatoms were on average 0.02 for the 1 st harvest. However for the 2 nd harvest carbon concentrations increased by typically 4 -fold (Fig. 1), resulting in average chl a:carbon ratios of 0.01 . The higher carbon levels at the 2nd harvest are likely to have been produced from the large amounts of dead cell material which were observed microscopically. Using regressions obtained from POC and biovolume data (Fig. 1) we predict that between 40 and $80 \%$ of the total POC in our 2nd harvest cultures was due to non-viable material. Low chl a:carbon ratios concurrent with an absence in pigment transformation products were also found in vertical depth profiles in the northeast Atlantic Ocean at the end of the spring bloom (Llewellyn \& Mantoura 1996). This suggests that similar production of large amounts of nonviable carbon may occur in the open ocean without the involvement of protozoan or zooplankton grazing. The high TPC levels in our cultures were paralleled by high particulate nitrogen values, suggesting that the particulate organic material associated with nonviable cells had a similar nitrogen content to that of viable cells.
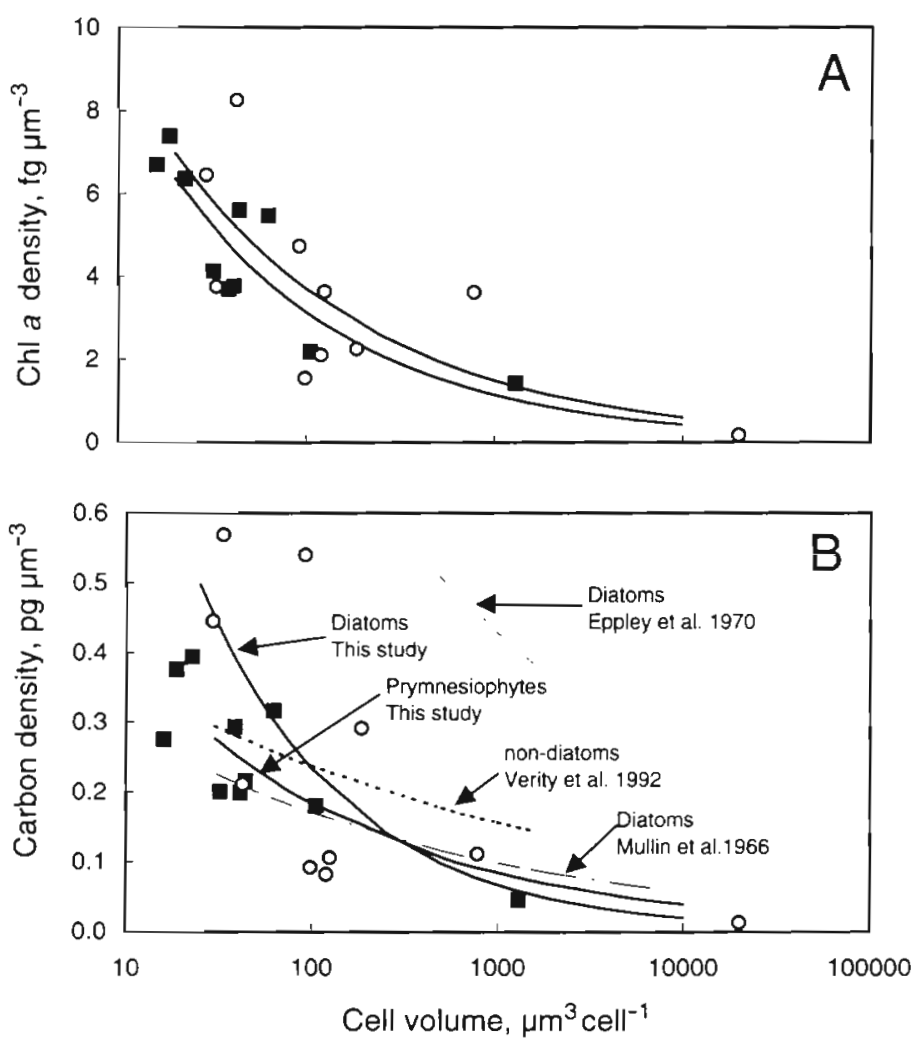

Fig. 2. (A) Chlorophyll a (chl a) and (B) carbon density (C) against cell volume for early growth (1st harvest) prymnesiophytes ( $\mathbf{\square}$ ) and diatoms (0). Regressions using least squares method:

prymnesiophyte: $\log _{10} \mathrm{chl} a=-0.441 \log _{10} V+1.38$,

$\mathrm{r}^{2}=0.75, \mathrm{p}=0.001$

diatom: $\log _{10} \mathrm{chl} a=-0.397 \log _{10} V+1.36$,

$I^{2}=0.5, p=0.02$;

prymnesiophyte: $\log _{10} C=-0.34 \log _{10} V-0.06$,

$\mathrm{r}^{2}=0.63, \mathrm{p}=0.006,95 \%$ confidence limits, intercept -0.17 to 0.4 , slope 0.61 to -0.29 ;

diatom: $\log _{10} C=-0.546 \log _{10} V+0.46$,

$\mathrm{r}^{2}=0.47, \mathrm{p}=0.028,95 \%$ confidence linits, intercept -0.45 to 0.9 , slope -0.72 to -0.17 .

Verity et al. (1992) for non-diatomaceous cells:

$\log _{10} C=-0.181 \log _{10} V-0.26, \mathrm{r}^{2}=0.64$.

Mullin et al. (1966) for predominantly diatoms:

$\log _{10} C=-0.241 \log _{10} V-0.29$.

Eppley et al. (1970) for diatoms:

$\log _{10} C=-0.24 \log _{10} V+0.35$

An alternative to using chl a as a proxy for microplankton carbon biomass is to determine the cell abundance and average cell volume and to estimate carbon from an empirically derived TPC per unit cell volume conversion factor (Booth et al. 1988, Sieracki at al. 1993). Regression models describing the relationship between carbon content and cell volume have been reported frequently (e.g. Mullin et al. 1966, Eppley et al. 1970, Moal et al. 1987, Verity et al. 1992). 
However, the relationships have typically been determined for larger phytoplankton that contain significant vacuolar space, not present in smaller nanophytoplankton. For both prymnesiophytes and diatoms in early growth, chl a and carbon density decreased

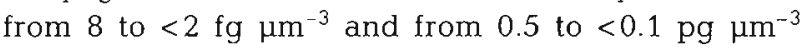
respectively as cell volume increased from 20 to over $1000 \mu^{3}$ (Fig. 2). Slope and intercept regressions of carbon density versus cell volume produced $95 \%$ confidence limits that encompassed those of previous studies on prymnesiophytes (Verity et al, 1992) and diatoms (Mullin et al. 1966, Eppley 1970) (Fig. 2).

\section{Biomineral correlations}

We also investigated the hypothesis that fuco and hex-fuco can be used as proxies for diatom-silicate and prymnesiophyte-calcite abundances respectively. Fuco within diatoms did not correlate with silicate across the class or within species examined for the 2 harvests. This is likely to be because fuco is relatively labile with high turnover rates (Goericke \& Welshmeyer 1992) whereas silicate decomposes slowly. For the prymnesiophytes, hex-fuco was found in 3 out of the 4 orders studied whereas calcite was found predominantly within the order Coccolithophorales. Therefore, in mixed communities of prymnesiophytes a correlation between calcite and hex-fuco is unlikely. In a situation where populations are dominated by 1 Coccolithophorales species, such as is known to occur during the North Atlantic spring bloom (Weeks et al. 1993), again, there is unlikely to be a correlation. This is because hex-fuco, like fuco, is a relatively labile pigment and its cellular concentration decreases as cells age (Table 3 ). In contrast, calcite coccoliths are cast off as cells age, increasing calcite concentrations rapidly (Table 5). Our results are consistent with findings in the marine environment, where $85 \%$ of the total carbon stored in the sedimentary sink is in the form of calcium carbonate, while only $15 \%$ is organic carbon (Westbroek et al. 1994). Thus, although carbonate transport out of the euphotic zone is dwarfed by the export of POC, the ultimate sink of carbonate is far greater than of organic carbon. We conclude that biomarker pigments cannot be used as proxies of biomineral abundance except for, perhaps, in an early bloom situation where Coccolithophorales dominate.

Acknowledgements. This study forms part of the Plankton Reactivity in Marine Environment (PRIME) community project. We thank Fauzi Mantoura and Ray Barlow for securing project funds; John Green and Michael Turner for the provision of culture isolates; Roger Harris and Cilla Course for assistance and advice on growing cultures and preparation of culture media; Glen Tarren for bacterial counts; Denise Cum- mings for assistance with pigment analysis; Gary Burt for assistance in calcite analysis: Alan Tapin and Rose Wood for help on statistical analysis; and Richard Geider and Roger Harris for their advice on earlier versions of the manuscript.

\section{LITERATURE CITED}

Barlow RG, Mantoura RFC, Gough MA, Fileman TW (1993) Pigment signatures of the phytoplankton composition in the northeastern Atlantic during the 1990 spring bloom. Deep-Sea Res 40:459-477

Barlow RG, Cummings DG, Gibb SW (1997) Improved resolution of mono- and divinyl chlorophylls $a$ and $b$ and zeaxanthin and lutein in phytoplankton extracts using reverse phase C-8 HPLC. Mar Ecol Prog Ser 161:303-307

Berger R, Liaaen-Jensen S, McAlister V, Guillard RRL (1977) Carotenoids of Prymnesiophyceae (Haptophyceae). Biochem Syst Ecol 5:71-75

Booth B, Lewin J, Lorenzen CJ (1988) Spring and summer growth rates of subarctic Pacific phytoplankton assemblages determined from carbon uptake and cell volumes estimated using epifluorescence microscopy. Mar Biol 98: $287-298$

Chrétiennot-Dinet MJ, Sournia A, Ricard M, Billard C (1993) A classification of the marine phytoplankton of the world from class to genus. Phycologia 32:159-179

Eppley RW, Reid FMH, Strickland JDH (1970) The ecology of the plankton off La Jolla, California, in the period April through September 1967 In: Strickland JDH (ed) Estimates of phytoplankton crop size, growth rate and primary production. Bull Scripps Inst Oceanogr 17:33-34

Fernandez E, Boyd P, Holligan PM, Harbour DS (1993) Production of organic and inorganic carbon within a largescale coccolithophore bloom in the northeast Atlantic Ocean. Mar Ecol Prog Ser 97:271-285

Fernandez E, Marañón E, Balch WM (1996) Intracellular carbon partitioning in the coccolithophorid Emiliania huxleyi. J Mar Syst 9:57-66

Gibb SW, Barlow RG, Cummings DG, Rees NW, Trees CC, Holligan PM, Sugget D (in press) Phytoplankton pigment distributions in the Atlantic Ocean between $50^{\circ} \mathrm{N}$ and $50^{\circ} \mathrm{S}$ : an assessment of basin scale variability. Prog Oceanogr

Goericke R, Welshmeyer NA (1992) Pigment turnover in the marine diatom Thalassiosira weissflogii. I. The ${ }^{14} \mathrm{CO}_{2}$ labelling kinetics of carotenoids. J Phycol 28:507-517

Jeffrey SW, Wright SW (1994) Photosynthetic pigments in the Haptophyta. In: Green JC, Leadbeater BSC (eds) The haptophyte algae. The Systematics Association Special Volume, No. 51. Oxford Science Publications, Oxford, p 111-132

King P, Kennedy $H$, Newton PP, Jickells TD, Brand T, Calvert $S$, Cauwet $G$, Etcheber $H$, Head $B$, Khripounoff $A$. Manighetti B, Miquel JC (1998) Analysis of total and organic carbon and total nitrogen in settling oceanic particles and a marine sediment: an interlaboratory comparison. Mar Chem 60:203-216

Klein B (1988) Variations of pigment content in two benthic diatoms during growth in batch culture. J Exp Mar Biol Ecol 115:237-248

Llewellyn CA, Mantoura RFC (1996) Pigment biomarkers and particulate carbon in the upper water column compared to the ocean interior of the northeast Atlantic. Deep-Sea Res 43:1165-1184

Mackey MD, Mackey DJ, Higgins HW, Wright SW (1996) CHEMTAX - a program for estimating class abundances 
from chemical markers: application to HPLC measurements of phytoplankton. Mar Ecol Prog Ser 144:265-283

Mantoura RFC, Llewellyn CA (1983) The rapid determination of chlorophylls and carotenoid pigments and their breakdown products in natural waters by reverse-phase highperformance Iiquid chromatography. Anal Chim Acta 151: $297-314$

Moal J, Martin-Jezequel Harris RP, Samain JF, Poulet SA (1987) Interspecific and intraspecific variability of the chemical composition of marine phytoplankton. Oceanol Acta 10:339-346

Montagnes DJS, Berges JA, Harrison PJ, Taylor FJR (1994) Estimating carbon, nitrogen, protein, and chlorophyll a from volume in marine phytoplankton. Limnol Oceanogr 39:1044-1060

Mullin MM, Sloan PR, Eppley RW (1966) Relationship between carbon content, cell volume, and area in phytoplankton. Limnol Oceanogr 11:307-311

Owens TG, Falkowski PG (1982) Enzymatic degradation of chlorophyll a by marine phytoplankton in vitro. Phytochemistry 21:979-984

Parsons TR, Maita Y, Lalli CM (1984) A manual of chemical and biological methods for sea water analysis. Pergamon Press, Oxford

Repeta DJ, Gagosian RB (1982) Carotenoid transformations in coastal marine waters. Nature 295:51-54

Sieracki ME, Verity PG, Stoecker DK (1993) Plankton community response to sequential silicate and nitrate depletion during the 1989 North Atlantic spring bloom. DeepSea Res 40:213-226

Stauber JL, Jeffrey SW (1983) Photosynthetic pigments in fifty-one species of marine diatoms. J Phycol 24:158-172

Takahashi K (1994) Coccolithophorid biocoenosis: production and fluxes to the deep sea. In: Green JC, Leadbeater BSC (eds) The haptophyte algae. The Systematics Association Special Volume, No. 51. Oxford Science Publications, Oxford, $\mathrm{p} 335-350$

Takahashi K, Broecker WS, Langer S (1985) Redfield ratio based on chemical data from isopycnal surfaces. J Geophys Res 90:6907-6924

Editorial responsibility: Otto Kinne (Editor), Oldendorf/Luhe, Germany
Verado DJ, Froelich PN, McIntyre A (1990) Determination of organic carbon and nitrogen in marine sediments using the Carlo Erba NA-1500 Analyzer. Deep-Sea Res 37: $157-165$

Verity PG, Smetacek V (1996) Organism life cycles, predation, and the structure of marine pelagic ecosystems. Mar Ecol Prog Ser 130:277-293

Verity PG, Robertson CY, Tronzo CR, Andrews MG, Nelson JR, Sieracki ME (1992) Relationships between cell volume and the carbon and nitrogen content of marine photosynthetic nanoplankton. Limnol Oceanogr 37:1434-1446

Weeks A, Conte $\mathrm{MH}$, Harris RP, Bedo A, Bellan I, Burkill PH, Edwards ES, Harbour DS, Kennedy $H$, Llewellyn CA Mantoura RFC, Morales CE, Pomroy AJ, Turley CM (1993) The physical and chemical environment and changes in community structure associated with bloom evolution: the Joint Global Flux Study North Atlantic Bloom Experiment. Deep-Sea Res 40:347-368

Westbroek P, Van Hinte JE, Brummer GJ, Veldhuis M, Brownlee C, Green JC, Harris R, Heimdal BR (1994) Emiliania huxleyi as a key to biosphere-geosphere interactions. In: Green JC, Leadbeater BSC (eds) The haptophyte algae. The Systematics Association Special Volume, No. 51. Oxford Science Publications, Oxford, p 321-334

Williams R, Claustre $H$ (1991) Photosynthetic pigments as biomarkers of phytoplankton populations and processes involved in the transformation of particulate organic matter at the Biontrans site $\left(47^{\circ} \mathrm{N} 20^{\circ} \mathrm{W}\right)$. Deep-Sea Res 38: $347-355$

Wright SW, Jeffrey SW, Mantoura RFC, Llewellyn CA, Björnland T, Repeta D, Welschmeyer $N$ (1991) Improved HPLC method of analysis of chlorophylls and carotenoids from marine phytoplankton. Mar Ecol Prog Ser 77:183-196

Yentsch CS, Menzel DW (1963) A method for the determination of phytoplankton chlorophyll and phaeophytin by fluorescence. Deep-Sea Res 10:221-231

Zubkov MV, Sleigh MA, Burkill PH, Leakey RJG (in press) Picoplankton community structure on the Atlantic Meridional Transect: a comparison between seasons. Prog Oceanogr

Submitted: May 29, 1999, Accepted: July 13, 1999

Proofs received from author(s): February 2, 2000 